\title{
Public-private partnership in the implementation of innovative urban development policy
}

\author{
Yulia Vertakova ${ }^{1}$, Tatyana Babich $^{2}$, and Olga Lebedenko ${ }^{2}$ \\ ${ }^{1}$ Financial University under the Government of the Russian Federation, Kursk branch, 305016, 3, \\ Lomonosova street, Kursk, Russia \\ ${ }^{2}$ Southwest State University, 94, 50 let Oktyabrya str., Kursk, 305040, Russia
}

\begin{abstract}
Many countries are moving to a new technological structure, caused by the 4th industrial and technological revolution. This transition is accompanied by the transformation of the previously existing territorial organization of the economy, infrastructure and resettlement, which relates to issues of urban development policy. In this case, coordination of the interests of the state and business is required. An effective tool in this area is public-private partnership (PPP). The main goal is the development of tools for the implementation of innovative urban development policy in the technological and social transformation of the economy. The methodological basis is the methodologies, approaches in the works of foreign and Russian scientists in the field of PPP research in the implementation of innovative urban policy. The main results of the study are following: 1.The modern task of urban development policy is the formation of a comfortable environment that will ensure a high standard of living for the population. 2. For the implementation of this task, the "adaptive territory" approach is suggested. 3 . The modern tool for this approach is PPP. The main conclusions and recommendations can be used to justify the mechanisms for implementing innovative urban development policy in order to harmonize the interests of the state and business in the implementation of the "adaptive territory" approach, which meets the modern development paths of the global economy.
\end{abstract}

\section{Introduction}

Modern world trends form the requirements for the need for an innovative way of developing the economy of any country, since this vector is aimed at ensuring a technological breakthrough, the country's international competitiveness, an increase in the standard of living of the population, and overall economic growth $[1,2,3]$. The standard of living of the country's population depends largely on the quality of the environment of their livelihoods, which is the result of the development of the territory - the improvement of the spatial organization of territorial arrangement carried out by urban development activities. At the same time, one of the modern tasks of the country's urban development policy should be aimed at creating such a comfortable environment that will allow the population to satisfy their needs for recreation, social contacts, economic activities, upbringing of the young generation and, on the whole, will ensure a high standard of living. It also refers to 
measures to ensure comfortable housing, social, industrial, transport and other engineering infrastructure, which are coordinated in the implementation of urban development policy. One of the mechanisms providing a solution to the problems in the field of urban development policy and coordination of interests at various levels of government is publicprivate partnership (PPP), which allows optimal coordination of the work of the state and business. Indeed, it is possible to obtain the maximum effect that ensures the country's economic growth at a high pace only with close interaction between the state and private individuals.

Currently, the PPP mechanism is actively used in various countries in the implementation of capital-intensive infrastructure projects in the development of social, transport, utilities, energy infrastructure and it operates at all levels of government. In accordance with the above, the relevance of researches aimed at developing methodology for the functioning of public-private partnerships in the implementation of innovative urban development policy is currently increasing.

Certain aspects of the researched problem were studied by economists in various aspects and directions. The fundamentals of using public-private partnership in the implementation of various areas of economic policy have been formed by such foreign scientists as D. Ramsey, M.E. Asmar [4], E.G. Pagoni, G. Patroklos [5], T.P. Ly, C. Zhang [6] and others. In Russia, these are A.V. Polyanin, T.A. Golovina [7], A.S. Belenky, G.G. Fedin, A.L. Kornhauser [8], I. Makarov, V. Plotnikov [9], S.S. Yatsechko [10], V.I. Grigor'ev [11] et al. But, despite the presence of significant research and fundamental approaches in this area, modern science is still not able to fully substantiate and methodologically provide a solution to a number of development management problems caused by the current change in the socio-economic environment. The content of this study covers an interconnected set of theoretical and applied problems related to improving the efficiency of urban development policy and its transition to the innovative path of development.

\section{Results}

World trends indicate that territorial development management is carried out on the basis of urban planning regulation.

Urban development policy in modern conditions is one of the main directions for the implementation of state economic policy at different levels on the spatial organization of territorial arrangement as a material environment for citizens. And since world trends testify to the need for an innovative way of economic development, this cannot fail to affect urban development policy [12].

It should be noted that in the theoretical developments and legal acts of different countries there are various interpretations of urban development policy. Having studied, and also compared them to modern development trends, the authors demarcated this concept. As a result, it is suggested that innovative urban development policy can be understood as the activity of state authorities and public administration aimed at innovative development and spatial organization of the territorial arrangement, ensuring the coordinated functioning of organizational structures in this area and achieving an increase in the well-being of society based on improving the quality of life of the population and implementing the chosen national economic development strategy through the use of set of methods, the choice of which is determined by the prevailing socio-economic situation in the country and the tendencies of its change.

The proposed interpretation of the innovative urban development policy determines not only the areas of territorial development (infrastructure development, the creation of capital construction objects), but also the main subjects involved in the integrated development of territories, the principles and main goals of this development. 
As a result, the following main organizational structures can be attributed to the main subjects that form and implement the urban development policy:

- public authorities competent to form and implement urban development policy;

- organizations, that conduct integrated research and design works on the spatial organization of the territorial arrangement through urban planning activities;

- organizations, that conduct survey works, the results of which are used in research on topics related to the problems of spatial organization of the territorial arrangement through urban development activities and in the development of project urban planning documentation;

- mass media that carry out educational functions regarding urban development policy;

- organizations that contribute to maintaining the required quality of the implementation of design decisions through architectural and construction control;

- the public, supervising urban development through public hearing procedures and other mechanisms.

Based on the analysis of program-targeted documents, empirical information on the implementation of urban development policy of individual countries of the world, a grouping of common factors that impede the implementation of innovative urban development policy has been carried out:

- by contents: informational, organizational and economic, regulatory, etc .;

- by the nature of the manifestation: imbalances as a result of growth, dysfunction of the existing environment;

- by object of influence: factors of the urban environment (infrastructure), factors of territorial development management.

The suggested classification of factors that impede the implementation of innovative urban development policy allows the authors to determine the expanded directions for applying innovations to solve these problems:

- the top hierarchy is occupied by strategic innovations "country - region agglomeration - city", which reflect the main ideas of global or national positioning, for example, "The country is an international trade center";

- at the second level there are innovations that improve the toolkit of urban development policy (urban planning legislation; urban development strategy at the country, region, agglomeration, city level; mechanisms of interaction between urban development participants; professional training system; information environment, etc.);

- at the third level there are innovations of organizations that are directly involved in urban planning activities (construction, reconstruction, repair and maintenance of capital facilities that form the urban environment, etc.).

It should be noted that at all levels of the presented hierarchy, it is recommended to implement marketing innovations, in particular, technologies for territorial branding, which allow obtaining a synergistic effect from their use.

It is known that the main tools of forming urban development policy in many countries of the world is territorial planning - planning of territorial development (changes in the spatial organization of the arrangement).

To substantiate the methodological aspects of the implementation of the innovative urban development policy, a classification of the main approaches to the definition of territorial planning as the main tool in this area has been formed (Table 1). 
Table 1. The main approaches to the definition of territorial planning as the main tool for the implementation of innovative urban development policy (compiled by the authors)

\begin{tabular}{|c|c|}
\hline Name of approach & Characteristic \\
\hline Municipal approach & $\begin{array}{l}\text { The main goal is to ensure the well-being and improvement of the municipal } \\
\text { territory, aimed at creating a comfortable residence of citizens in the territory }\end{array}$ \\
\hline $\begin{array}{l}\text { Confessional } \\
\text { Approach }\end{array}$ & $\begin{array}{l}\text { The main unit of consideration is the city. However, the disadvantage of this } \\
\text { approach is the lack of a more definite concept of sustainable development. It is } \\
\text { only asserted that development is something that does not harm subsequent } \\
\text { residents and generations }\end{array}$ \\
\hline $\begin{array}{l}\text { Engineering } \\
\text { approach }\end{array}$ & $\begin{array}{l}\text { The development of engineering infrastructure, namely the main emphasis in this } \\
\text { approach is placed on the technological development of the territory }\end{array}$ \\
\hline Systems approach & $\begin{array}{l}\text { The approach considers the territory as a system consisting of various subsystems. } \\
\text { An example of an element of a subsystem can be a society, separate sections and } \\
\text { other subjects that have at least some independence in functioning and their own } \\
\text { structure }\end{array}$ \\
\hline $\begin{array}{l}\text { Legal (regulatory) } \\
\text { approach }\end{array}$ & $\begin{array}{l}\text { The development of territories, including the establishment of functional zones, } \\
\text { determining the planned location of state (federal), regional and municipal facilities }\end{array}$ \\
\hline Managerial approach & $\begin{array}{l}\text { The activities of state authorities and local government in establishing and } \\
\text { approving regulations on the development of territories, locations for facilities for } \\
\text { state and municipal needs. At the same time, territorial planning is carried out in } \\
\text { three directions: strategic, tactical and current. }\end{array}$ \\
\hline $\begin{array}{l}\text { Methodological } \\
\text { approach }\end{array}$ & The branch of practical activity that uses various methods of territorial planning \\
\hline $\begin{array}{l}\text { Adaptive territory } \\
\text { approach }\end{array}$ & $\begin{array}{l}\text { It considers the territory as a producer of services for the population of a given } \\
\text { territory. With this approach, a territory is a "service", which is assessed using a } \\
\text { specialized system of indicators based on consumer reactions, which obviously } \\
\text { includes the right of self-government }\end{array}$ \\
\hline
\end{tabular}

It should be noted that it is the "adaptive territory" approach that, according to the authors, is the most capacious and substantial, meeting modern development paths and allowing to analyze in detail the foreign and Russian experience in the integrated development of territories and implement innovative urban development policy paths. The approach of the "adaptive territory" also suggests that the organizational structures that shape and implement the urban development policy should be based on and proceed from the interests of the population living in this territory. As a result, it is possible to substantiate the basic principles for implementing the "adaptive territory" approach to the implementation of innovative urban development policy, which do not exclude, but supplement those principles that are indicated in the regulatory legal acts of urban development policy of countries:

- the principle of participation: the formation of urban development policy directions based on the interests of the population living in this territory, as well as interaction with lower levels of government, providing them with the opportunity to make decisions, which will help to increase the final efficiency from the implementation of development projects;

- the principle of sustainability includes the presence of long-term plans, prospects and forecasts in development. This principle also involves the formation of a concept (strategy) for the development of urban planning activities. It should be noted that not in all countries of the world, urban development policy has a strategic development goal, which should be aimed at ensuring the security of sustainable development of the territory, capital construction projects, etc., creating better conditions for human life and activity;

- the principle of balanced development of territories: harmonization of interests of various entities, as well as ensuring stability as the constant preservation of certain proportions in the development of territories;

- the principle of information consistency provides coordination of information at all levels of management; 
- the principle of holism: coordination of interests both vertically and horizontally. The addition to this principle is also the coordination of territorial and sectoral interests, that ensures the interaction of territorial development with the economic situation and sectoral characteristics;

- the principle of efficiency : the achievement of goals in a cost-effective manner, as well as the use of modern management technologies and mechanisms that meet the challenges of the modern economy;

- the principle of synergies : combining efforts and resources of institutional subsystems for the purpose of socio-economic and innovative development of territories.

The modern tool for implementing the "adaptive territory" approach is the use of PPPs.

It should be noted that in recent decades there has been a tendency in the world to develop relations between the state and business, due to the fact that this type of relationship is favorable for both parties. For business, relationships of this kind are the guarantor of obtaining financial resources at objects that belong to the state, and for the state this is a good option for acquiring financial assets of a business and managing it at state-owned objects by private individuals.

The need for the development of territories, including infrastructure facilities, as well as the growing interest of companies in the development of new areas of activity, has led to a significant increase in public authorities' activity for the development of PPPs in recent years $[13,14]$. These trends, as well as the need to attract business to the development of Russian infrastructure, have been introduced at the highest political level. This means that when implementing the directions of state economic policy in a strategic perspective, it is necessary to develop new forms of partnership with business. Therefore, a significant role in the modernization of the Russian economy and the development of infrastructure is assigned to the use of PPPs in urban development.

In the article, under the public-private partnership in urban planning it is suggested to understand the institutional and organizational alliance between the state and business, carried out on a contractual basis between the state (municipal) government bodies of urban planning and private structures, in which the subject of the agreement is state (municipal) property or services aimed at the development of territories, which is achieved by attracting private investment and distribution of risks among partners.

The analysis of the practice of using PPPs in Russia and abroad has been carried out. Comparing the definitions that reveal the essence of partnerships between the state and business, it should be noted that Russian and foreign authors imply different semantic approaches. While foreign authors give priority to private business (public-private partnership), in Russian practice there is a public-private partnership that gives priority to public authorities, which reflects the mentality and characteristics of the existing relations. The transition to partnership means a partial and time-dependent transfer of some functions of the state to the private sector, which are permitted by law and drawn up by agreement. It has been established that PPP is currently a common form of interaction between the state and the private sector in European countries: the leading countries for implementing PPP projects in Europe are England, France, Greece, Belgium, Spain and the Netherlands.

The authors also analyzed the features of PPP in the framework of BRICS. The most common PPP projects in the urban development of these countries are water supply, sewage system, energy, transport [15]. The largest number of PPP projects is implemented according to the Build-Own-Transfer (BOT) model, which is based on private ownership of the facility and is the most convenient for all BRICS member countries. This model assumes that the state provides private companies with the opportunity to carry out projects for a certain time in order to make a profit. After this period, a private company transfers the project to the state free of charge. 
There has been conducted an analysis of the possession of a unified (federal) specific law on PPPs by individual countries of the world (Table 2).

Table 2. The possession of legislation on PPP at the macro level by certain countries of the world (compiled by the authors)

\begin{tabular}{|c|c|}
\hline Country & The law "On the PPP" at the macro level \\
\hline Russia & $\begin{array}{c}\text { FZ dated 13.07.2015 of №224-FZ "On the PPP, MPP in the Russian Federation and } \\
\text { Amendments to Certain Legislative Acts of the Russian Federation"; FZ of } \\
\text { 21.07.2005 №115-FZ "On Concession Agreements" }\end{array}$ \\
\hline USA & Missing \\
\hline France & $\begin{array}{c}\text { Introduction of PPP Contracts - Government Decree №2004 - } 559 \text { of } 17 \text { June } 2004 \\
\text {; The law "On the PPP contracts») № 2008-735 of July 28, } 2008\end{array}$ \\
\hline Germany & $\begin{array}{c}\text { The lack of (the law "On the acceleration of PPP" - } 2005 \text { - a number of } \\
\text { amendments to the legislation) }\end{array}$ \\
\hline Italy & Missing \\
\hline Great Britain & Missing \\
\hline Turkey & Missing \\
\hline Belgium & Missing \\
\hline Poland & The law "On the PPP", 2008 \\
\hline The Netherlands & Missing \\
\hline Spain & Missing \\
\hline Portugal & The law «On PPP», 2012 \\
\hline Ireland & The law on PPP from March 22, 2002 \\
\hline Serbia & $\begin{array}{l}\text { The law "On Concessions and PPP» №88 / } 2011 \text { (as amended. №13 / } 2012 \text { and } \\
\text { 108/2012) }\end{array}$ \\
\hline Greece & The law "On the PPP", $3389 / 2005$ \\
\hline
\end{tabular}

As a result, the possibilities of PPP in the implementation of innovative urban development policy were justified (Fig. 1).

Thus, the mechanism of public-private partnership, being one of the most important forces of social development, in the future may become a source of continuous economic development of the territory. At the same time, the experience of all levels of government shows that it is not enough only to announce the transition to PPP. It is necessary to purposefully implement a new type of public policy - the policy of public-private partnership. 


\section{INNOVATIVE URBAN DEVELOPMENT POLICY}

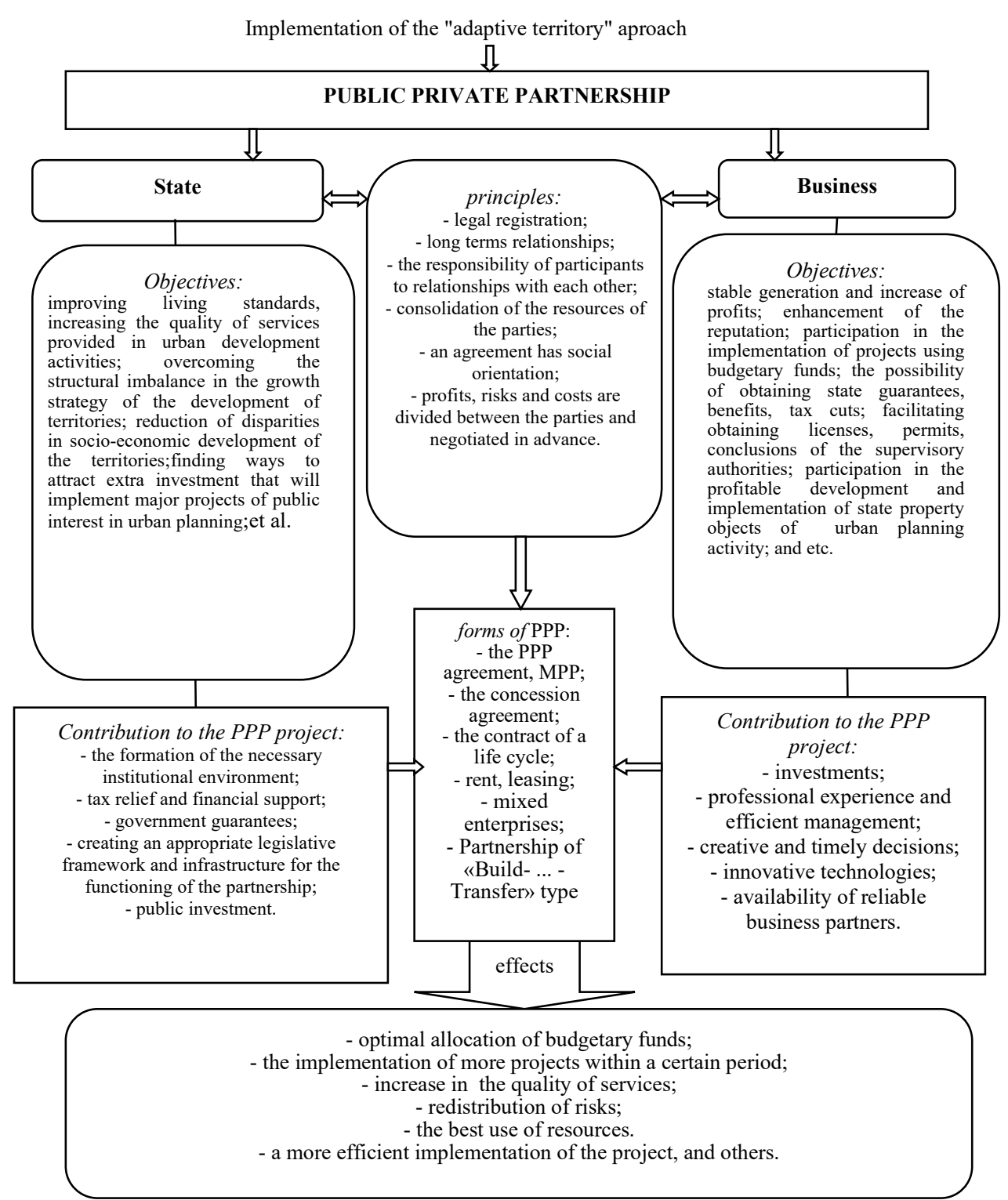

Fig. 1. PPP mechanism in the implementation of innovative urban development policy (compiled by the authors)

\section{Conclusion}

One of the main modern tasks of urban development policy in any country is the formation of a comfortable environment that will allow the population to satisfy their needs for recreation, social contacts, economic activities, education of the young generation and in general will provide a high standard of living. 
Currently, there are tendencies of strengthening state regulation in urban planning, aimed not only at improving the living standards of the population, but also at maintaining a balance of interests of various sectors of society related to the conditions for using real estate, the possibility of choosing places of work and rest, taking into account their availability. The interpretation of the innovation urban development policy has been suggested, which allowes to clarify not only the areas of development of the territories (infrastructure development, creation of capital construction facilities), but also the main subjects involved in the integrated development of territories, the principles and main goals of this development. There has been carried out a grouping of common factors that impeded the implementation of innovative urban development policy in modern conditions. It has also allowed to identify expanded directions for applying innovations to solve these problems in urban planning. To substantiate the methodological aspects of the implementation of innovative urban development policy, a classification of the main approaches to the definition of spatial planning as the main tool in this area has been formed. The modern approach of the "adaptive territory", which corresponds to modern development paths, is highlighted, which allows the to analyze the foreign and Russian experience in the integrated development of territories in detail and implement innovative development paths of urban planning.

The modern tool for implementing the "adaptive territory" approach is PPP, by which in urban planning it is proposed to understand the institutional and organizational alliance between the state and business, carried out on a contractual basis between state (municipal) urban planning authorities and private entities, in which the subject of the agreement is state (municipal) property or services aimed at the development of territories, which is achieved through attraction of private investment and risk-sharing among the partners.

\section{References}

1. S. Bodrunov, V. Plotnikov, Proceedings of the 30th International Business Information Management Association Conference, 2658-2665, (2017).

2. Y. Vertakova, T. Babich, E. Bykovskaya, Proceedings of the 33rd International Business Information Management Association Conference, 2901-2908, (2019).

3. Y. Vertakova, T. Babich, Proceedings of the 30th International Business Information Management Association Conference, 1844-1850, (2017).

4. D. Ramsey, M.E. Asmar, J. Leg. Aff. \& Disp. Res. in Eng. \& Const. 12 (1), (2020).

5. E.G. Pagoni, G. Patroklos, Sim. Mod. Pract. \& Th. 97, (2019).

6. T.P. Ly, C. Zhang, As. Pac. J. of Tour. Res. 24 (12), 1109-1125, (2019).

7. Y.V. Vertakova, A.V. Polyanin, T.A. Golovina, Eur. Res. Stud. J. 21, 1001-1012, (2018).

8. A.S. Belenky, G.G. Fedin, A.L. Kornhauser, Int. J. of Pub. Adm. 42 (15-16), 12751310 (2019).

9. I. Makarov, V. Plotnikov, MATEC Web of Conferences, 170, (2018).

10. S.S. Yatsechko. Lect. Not. in Net. and Syst. 73, 709-716, (2020).

11. V.I. Grigor'ev, V.A. Plotnikov. Teor. i Prakt. Fiz. Kult. 8, 102-104, (2014).

12. A. Das, B. Dahiya. Adv. in 21 st Cent. Hum. Set. 353-384, (2020).

13. V. Plotnikov, I. Makarov, et al. E3S Web of Conferences, 91, (2019).

14. H. Wang, W. Xiong, L. Yang, D. Zhu, Z. Cheng, Cities, 96, (2020).

15. S. Khetrapal, A. Acharya, A. Mills, Soc. Sc. and Med. 243, (2019). 